\title{
Pressurized hot water extraction of Scots pine sapwood: effect of wood size on obtained treatment products
}

\author{
Suvi Kyyrö ${ }^{1}$ (i) $\cdot$ Michael Altgen ${ }^{1} \cdot$ Lauri Rautkari $^{1}$ \\ Received: 30 May 2020 / Revised: 22 July 2020 / Accepted: 24 July 2020 / Published online: 3 August 2020 \\ (C) The Author(s) 2020
}

\begin{abstract}
The efficiency of hot water extraction (HWE) is dependent on the size of treated wood. While previous research regarding this size-effect has focused on HWE treating sawdust and wood chips, this study investigated its effect on wood blocks with precise dimensions and a broad range of treatment conditions. Scots pine (Pinus sylvestris L.) sapwood samples with dimensions of $10 \times$ $10 \times 20 \mathrm{~mm}^{3}$ and $25 \times 25 \times 50 \mathrm{~mm}^{3}(\mathrm{R} \times \mathrm{T} \times \mathrm{L})$ were HWE treated at $130-170{ }^{\circ} \mathrm{C}$ for $40-200 \mathrm{~min}$ using liquid-to-solid ratios of 4-20. Our results showed that wood mass loss, which was primarily caused by the decomposition of hemicelluloses, was larger when using small samples. This was mainly assigned to a higher quantity of acetone-soluble decomposition products that remained within the large samples, due to longer distances for diffusion and mass transfer from the wood blocks to the extraction liquid. In line with wood mass loss differences, the amount of dissolved compounds (i.e., carbohydrates) in the extraction liquid at different treatment severities was dependent on the wood size, while the liquid-to-solid ratio had only modest effects. However, composition changes of the extraction liquid, in particular changes in the proportion of poly- and monocarbohydrates with increasing treatment severity, were similar for both sample sizes.
\end{abstract}

Keywords Chemical composition $\cdot$ Hemicellulose extraction $\cdot$ Hydrolysis $\cdot$ Treatment severity $\cdot$ Wood degradation

\section{Introduction}

Pressurized hot water extraction (HWE) is based on treating wood in water that is heated to temperatures between 100 and $240{ }^{\circ} \mathrm{C}$ and kept in liquid phase with sufficiently high pressure $[1,2]$. Studies on HWE are typically applied to wood sawdust, particles, or chips [1] to obtain hemicelluloses that can be utilized as feedstock for biofuel production $[2,3]$ or for the conversion into high-value-added products $[2,4,5]$. The solid residue can be used for the pulp and paper production $[2,3,6]$ and has also a potential for the use in engineered wood products such as wood plastic composites [7], particleboards [8], or oriented strand boards [9]. HWE may also serve as an alternative to the thermal modification of solid wood. Thermal modification utilizes the partial degradation of wood at elevated temperatures to enhance the hygroscopic

Suvi Kyyrö

suvi.kyyro@aalto.fi

1 School of Chemical Engineering, Department of Bioproducts and Biosystems, Aalto University, P.O. Box 16300, 00076 Aalto, Espoo, Finland properties and decay resistance of solid wood products [10]. While HWE is less efficient in decreasing the hygroscopicity $[11,12]$ or decay resistance $[13]$ of wood compared with thermal modification, it enables the utilization of removed hemicelluloses and limits the loss in strength and toughness of the solid residue [14]. However, increasing the wood size may have a significant effect on the effectiveness of HWE and the obtained treatment products.

The effectiveness of HWE treatments is based on the selective hydrolysis of some wood components, while other components resist hydrolytic degradation. At high temperature and pressure, water obtains acidic properties, which initiates the hydrolysis of wood components. As wood starts to degrade, acetic acid and other organic acids are formed, which further increase the degradation rate of wood [15-17]. Hemicelluloses as structural constituents in wood are sensitive to hydrolysis and are first to degrade into smaller, watersoluble oligo- and monomers [16, 18-20]. While most of the lignin resists thermal degradation considerably better than hemicellulose, delignification of the wood in hot water occurs at sufficiently high temperatures [21]. However, delignification kinetics is dominated by simultaneous degradation and condensation reactions of lignin. Some of the 
lignin partially transforms into the acetone-soluble form [22], which may be observed as condensed lignin droplets on surfaces of HWE-treated wood cell walls [19].

The efficiency of wood HWE is dependent on a number of treatment conditions, such as the temperature, the treatment time, and the liquid-to-solid ratio (L/S ratio). With sufficiently long treatment times, small amounts of hydrophilic wood components can be extracted even at temperatures lower than $100{ }^{\circ} \mathrm{C}[2,23,24]$. However, it has been suggested that efficient hemicellulose extraction requires temperatures of at least $140-160{ }^{\circ} \mathrm{C}[9,18,23]$. At sufficient temperatures, HWE treatment times shorter than 30 min already result in large hemicellulose yields from wood chips or sawdust $[6,18$, $25]$. When the treatment temperature is too high or the treatment time too long, crystalline cellulose starts to degrade, and extracted hemicelluloses degrade rapidly into acids and furan derivatives $[16,18,19,26]$. Previous research has also indicated that variations in $\mathrm{L} / \mathrm{S}$ ratio have an effect on the hemicellulose extraction efficiency, but contradictory results have been reported. Tunc [27] suggested that increasing the L/S ratio decreases the hemicellulose extraction yield and increases the lignin removal, while Garrote et al. [28] deemed the effect of the L/S ratio negligible. Leschinsky et al. [29] suggested that variations in experimental setups could explain such contradictory results.

Besides treatment temperature and time, previous studies found a significant effect of the wood size on the obtained treatment products. Increasing the wood size from fine wood meal up to coarse wood chips decreases the hemicellulose extraction rate and the average molecular weight of the obtained hemicelluloses. This is mainly assigned to a longer path that the dissolved hemicelluloses need to diffuse from wood matrix into the bulk extraction water [30-32]. However, previous studies on the wood during HWE are limited to particles as large as chips, which typically have at least one dimension $\leq 3 \mathrm{~mm}$ [1]. Our present study investigates this phenomenon for larger samples of sawn timber with precise dimensions. In contrast to earlier studies, we investigated the wood size effect during HWE for a broad range of treatment conditions, including temperature-time environments reaching from $130{ }^{\circ} \mathrm{C}$ and $40 \mathrm{~min}$ to $170^{\circ} \mathrm{C}$ and $200 \mathrm{~min}$, as well as $\mathrm{L} / \mathrm{S}$ ratios between 4 and $20 \mathrm{~g} / \mathrm{g}$. Our results on chemical composition changes in the solid residue and the extraction liquid may help in optimizing the HWE conditions to maximize the yield of high molecular weight hemicelluloses from wood.

\section{Material and methods}

\subsection{Material}

The wood used for experiments was Scots pine (Pinus sylvestris L.) sapwood. Samples were prepared from kiln-dried boards in two different dimensions: small $10 \times 10 \times 20 \mathrm{~mm}^{3}$ and large $25 \times$ $25 \times 50 \mathrm{~mm}^{3}(\mathrm{R} \times \mathrm{T} \times \mathrm{L})$. The samples did not contain heartwood, knots, or visible defects. The average dry density of the samples was $0.46 \pm 0.04 \mathrm{~g} / \mathrm{cm}^{3}$. The samples that originated from different boards were distributed evenly over the different sample groups. Reference samples were prepared and treated the same as the HWE samples, except that no HWE was performed. Figure 1 summarizes the treatment procedure and utilized analytical methods for samples.

\subsection{Hot water extraction}

All samples were oven-dried at $105{ }^{\circ} \mathrm{C}$ for $24 \mathrm{~h}$ to determine their initial dry mass and then vacuum-impregnated with deionized water for $24 \mathrm{~h}$ at 50 mbar until reaching full watersaturation prior to the HWE treatment. The HWE treatment was performed in an air-bath reactor (Haato Oy, Model 16140-538, Vantaa, Finland) with space for up to six treatment vessels that had a volume of 2.51 . The samples were placed in the treatment vessels together with a pre-determined



Fig. 1 Treatment procedure for Scots pine sapwood samples 
amount of deionized water to result in L/S ratios of either 4, 10, or $20 \mathrm{~g} / \mathrm{g}$ based on the dry mass of the wood. The vessels were sealed and the water temperature within the vessel was gradually risen to the peak temperature, which was held for durations between 40 and $200 \mathrm{~min}$ before the vessels were cooled down under running tap water. Different treatments with various combinations of treatment temperatures, treatment times, and L/S ratios were conducted (see Table 1). Each treatment condition combination was applied to either 40 small samples $(10 \times 10 \times$ $\left.20 \mathrm{~mm}^{3}\right)$ or 8 large samples $\left(25 \times 25 \times 50 \mathrm{~mm}^{3}\right)$.

\subsection{Treatment severity}

The severity factor (also known as P-factor) was used to quantify the combined effect of treatment temperature and duration during the HWE treatment. The severity factor $\left(\log \mathrm{R}_{0 \mathrm{HWE}}\right)$, of each HWE treatment, was calculated based on the equation given by Overend and Chornet [33]. In order to account for wood decomposition that occurred before the peak temperature was reached, the severity factor during the heating phase was included in $\log \mathrm{R}_{0 \mathrm{HWE}}$. Assuming that no significant wood decomposition took place at temperatures $\leq 100{ }^{\circ} \mathrm{C}$, the severity factor of the whole HWE process (log $\left.\mathrm{R}_{0 \mathrm{HWE}}\right)$ could be calculated according to Eq. 1:

Table 1 Treatment conditions applied to Scots pine sapwood samples during hot water extraction

\begin{tabular}{|c|c|c|c|}
\hline No. & Peak temperature $\left({ }^{\circ} \mathrm{C}\right)$ & Peak duration (min) & Liquid/solid (g/g) \\
\hline 1 & 130 & 40 & 20 \\
\hline 2 & 130 & 80 & 20 \\
\hline 3 & 130 & 120 & 20 \\
\hline 4 & 130 & 160 & 20 \\
\hline 5 & 130 & 200 & 20 \\
\hline 6 & 150 & 40 & 20 \\
\hline 7 & 150 & 80 & 20 \\
\hline 8 & 150 & 120 & 20 \\
\hline 9 & 150 & 160 & 20 \\
\hline 10 & 150 & 200 & 20 \\
\hline 11 & 170 & 40 & 20 \\
\hline 12 & 170 & 80 & 20 \\
\hline 13 & 170 & 120 & 20 \\
\hline 14 & 170 & 160 & 20 \\
\hline 15 & 170 & 200 & 20 \\
\hline $16^{\mathrm{a}}$ & 130 & 120 & 4 \\
\hline $17^{\mathrm{a}}$ & 150 & 120 & 4 \\
\hline $18^{\mathrm{a}}$ & 170 & 120 & 4 \\
\hline $19^{\mathrm{a}}$ & 130 & 120 & 10 \\
\hline $20^{\mathrm{a}}$ & 150 & 120 & 10 \\
\hline $21^{\mathrm{a}}$ & 170 & 120 & 10 \\
\hline
\end{tabular}

${ }^{\text {a }}$ Only applied to large samples with size of $25 \times 25 \times 50 \mathrm{~mm}^{3}$ $\log \mathrm{R}_{0 \mathrm{HWE}}=\log \left(\int_{t_{b}}^{t} \exp \left[\left(T-T_{\mathrm{b}}\right) / \omega\right] d t\right)$,

where $t$ is the duration of HWE treatment ( $\min ), t_{b}$ is the time (min) when $T_{b}$ was reached, $T$ is the temperature profile of HWE treatment $\left({ }^{\circ} \mathrm{C}\right), T_{b}$ is the reference temperature, and $\omega$ is the activation energy. The reference temperature, $T_{\mathrm{b}}$, and activation energy, $\omega$, were set to $100^{\circ} \mathrm{C}$ and 14.75 , respectively, which was based on previous studies [26, 33-35].

\subsection{Separation and treatment of extraction liquid and solid residue}

Extraction liquid and solid wood residues were separated with 50-micron filtering cloth. A small volume (ca. $5 \mathrm{ml}$ ) of the extraction liquid was used for the determination of acidsoluble lignin. The treated wood samples were leached with deionized water and a L/S ratio of ca. 10 on a flat-bed horizontal shaker for $48 \mathrm{~h}$ at room temperature. After waterleaching, extraction liquid and leaching liquid were combined and mixed. The mixture was stored in the freezer at $-20{ }^{\circ} \mathrm{C}$ until the analyses. The treated and water-leached wood samples were first conditioned at $20^{\circ} \mathrm{C}$ and $65 \%$ relative humidity for 2 weeks and then dried in an oven that was heated using a temperature sequence of $40,60,80$, and finally $105^{\circ} \mathrm{C}$, with each temperature being held for ca. $24 \mathrm{~h}$.

\subsection{Wood mass loss}

The mass loss (ML) of each sample caused by HWE treatment was calculated based on the initial dry mass of each wood sample and the dry mass after the HWE treatment and water-leaching using Eq. 2:

$M L=\left(m_{0}-m_{\mathrm{HWE}}\right) / m_{0} \times 100 \%$,

where $m_{0}$ is the initial dry mass before HWE treatment $(\mathrm{g})$, and $m_{\mathrm{HWE}}$ is the dry mass after HWE treatment and waterleaching $(\mathrm{g})$.

The corrected mass loss was calculated by taking the effect of acetone-soluble compounds into account according to the equation by Altgen et al. [36], who performed this correction for water-soluble compounds. The corrected mass loss was based on the dry and extractive-free mass before and after the treatment. The determination of acetone-soluble content in untreated reference samples and HWE-treated samples used for the calculation of the corrected mass loss is described in Section 2.7.

\subsection{Scanning electron microscopy}

Small and large samples from selected HWE treatments with similar levels of corrected mass loss (approx. $25 \%$ ) were chosen for scanning electron microscopy (SEM) analysis. 
Small blocks with dimensions of ca. $5 \times 10 \times 5 \mathrm{~mm}^{3}(\mathrm{R} \times \mathrm{T} \times$ $\mathrm{L})$ were cut from the samples. Half of the chosen samples were vacuum-impregnated with deionized water for $1 \mathrm{~h}$ at ca. 50 mbar, which was followed by water-leaching for 5 days with daily water changes. The other half of the chips were first extracted with acetone in a Soxhlet apparatus according to standard TAPPI T $204 \mathrm{~cm}-97$ [37], followed by drying at room temperature for ca. $24 \mathrm{~h}$, before the same waterleaching protocol was applied. After water-leaching, small chips (ca. $1.5 \times 3 \times 3 \mathrm{~mm}^{3}, \mathrm{R} \times \mathrm{T} \times \mathrm{L}$ ) were cut from the radial surface that was exposed to the extraction liquid during HWE using a razor blade and a sledge microtome. The SEM chips were dried at $50{ }^{\circ} \mathrm{C}$ for $2 \mathrm{~h}$, mounted on aluminum specimen stubs with carbon conductive tape, and sputtercoated (sputter coater Q150R, Quorum Technologies, Lewes, United Kingdom) with gold-palladium $(\mathrm{Au} / \mathrm{Pd}$ 80:20). The coated samples were observed with a scanning electron microscope (Sigma VP, Zeiss, Germany) using a beam acceleration voltage of $1 \mathrm{kV}$.

\subsection{Composition of solid wood residues}

The chemical composition of solid wood residue was determined for all sample groups, except those with a peak duration of 80 and $160 \mathrm{~min}$. From each sample group, samples that originated from the same board were chosen and ground into wood powder in a Wiley-mill (model 2) to pass through a 30-mesh screen. Moisture and ash content were measured based on EN-1318:2002 [38] and TAPPI T 211 [39] respectively. Acetone-soluble compounds were determined in a Soxhlet apparatus according to TAPPI T $204 \mathrm{~cm}-$ 97 [37]. Structural carbohydrates and lignin were analyzed by acid hydrolysis according to NREL/TP-510-42618 [40]. Monosaccharides were analyzed by high-performance anion-exchange chromatography with pulsed amperometric detection (HPAEC-PAD), as described previously by Lillqvist et al. [12] The lignin content was determined gravimetrically as the acidinsoluble fraction after drying at $103{ }^{\circ} \mathrm{C}$ for $12 \mathrm{~h}$. The amount of acid-soluble lignin was measured only for the reference samples since its amount in HWE-treated wood is very low in comparison with Klason lignin [41]. This was confirmed for intensively HWEtreated samples, which showed acid-soluble lignin content on dry wood weight of less than $0.6 \%$. The contents of cellulose and hemicellulose were calculated according to Janson [42]. All measurements were done in triplicate.

\subsection{Composition of the leachates}

Dissolved components in the extraction liquid were analyzed for the same sample groups as described in Section 2.7. Acid-soluble lignin content was analyzed for the extraction liquid within $6 \mathrm{~h}$ after the treatment process according to NREL/TP-510-42618 [40] in a Shimadzu UV-2550 spectrophotometer using a wavelength of $205 \mathrm{~nm}$ and an absorptivity constant of $110 \mathrm{~g} \mathrm{l}^{-1} \mathrm{~cm}^{-1}$.
All other analyses were conducted on a mixture of extraction and leaching water. The amount of total dissolved solids (TDS) and the ash content were measured according to standards EN 15216:2007 [43] and SFS 3008 [44] respectively. Monocarbohydrates in the water mixture were analyzed by HPAEC-PAD without prior prehydrolysis. The total carbohydrate content in the water mixture was analyzed in the same way, except that the polycarbohydrates were hydrolyzed in diluted sulfuric acid prior to the analysis according to NREL/TP510-42623 [45]. The polycarbohydrate content in the water mixture was calculated by subtracting the monocarbohydrate concentration from total carbohydrate concentration.

Based on the results, the amount of extracted compounds (EC) was calculated according to Eq. 3:

$E C=m_{\mathrm{ext}} / m_{0} \times 100 \%$,

where $m_{0}$ is the initial dry mass of the wood sample before HWE treatment $(\mathrm{g})$, and $m_{\text {ext }}$ is the dry mass of extracted component $(\mathrm{g})$. This calculation was applied to the amount of extracted polycarbohydrates, monocarbohydrates, acidsoluble lignin, and inorganic compounds. The amount of inorganic compounds was calculated based on the ash content of the extraction liquid. Furthermore, the amount of undetermined organic compounds was calculated by subtracting measured organic compounds from the TDS. Finally, the amount of undetermined mass loss was calculated by subtracting the TDS from the ML that was calculated according to Eq. 2 .

Extracted carbohydrate content was further investigated by comparing each carbohydrate fraction. Each carbohydrate fraction, polycarbohydrates, arabinose, rhamnose, galactose, glucose, xylose, and mannose, was compared with the overall carbohydrate content according to Eq. 4.

$C=m_{\mathrm{c}} / m_{\mathrm{all}} \times 100 \%$

where $m_{\text {all }}$ is the dry mass of all extracted carbohydrates (g), and $m_{\mathrm{c}}$ is the dry mass of the extracted carbohydrate fraction $(\mathrm{g})$.

\section{Results and discussions}

\subsection{Mass loss}

The results illustrated that the mass loss of Scots pine sapwood was not only a function of the applied HWE treatment temperature and time but was also influenced by the sample size. Figure 2a shows the course of the mass loss over the peak duration for all treatment temperatures and sample sizes. Except for short treatments at low temperatures $\left(130{ }^{\circ} \mathrm{C}\right)$, higher mass losses were achieved with small samples. Small samples also resulted in a larger mass loss rate for treatments at 130 and $150{ }^{\circ} \mathrm{C}$ compared with large samples, as shown by the slopes of the regression curves. However, considerable 

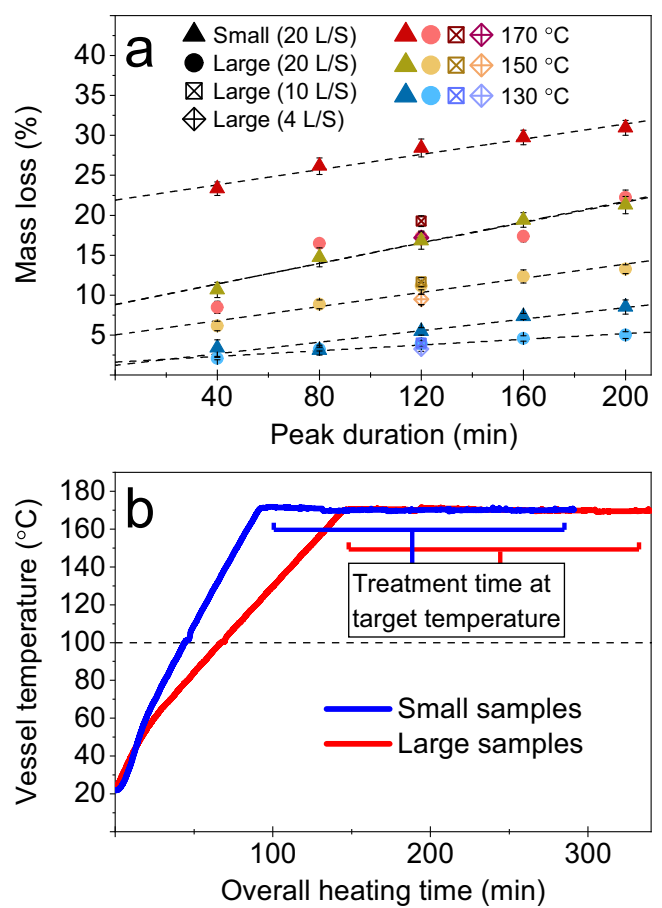

Fig. 2 Mass loss (\%) of Scots pine sapwood in relation to the peak duration (min) (a) and temperature of HWE treatment vessels $\left({ }^{\circ} \mathrm{C}\right)$ in relation to the overall heating time (min), when ratio $20 \mathrm{~L} / \mathrm{S}$ and target temperature $170{ }^{\circ} \mathrm{C}(\mathbf{b})$, error bars in (a) represent the standard deviation

mass loss was already obtained after short treatment peak durations (40 $\mathrm{min}$ ) and the intercepts of the regression curves with the $y$-axis indicated that wood decomposition occurred during the heating phase before the target temperature was reached $[2,23,36]$. The application of higher treatment temperatures enhanced this effect, because this prolonged the heating phase and the time that the samples were exposed to temperatures capable of decomposition.

While this effect was observed for both sample dimensions, it should be noted that the treatments of small and large samples were performed at different vessel loads to maintain a constant L/S ratio. Smaller vessel loads during treatments of small samples resulted in a shorter heating phase compared with treatments of large samples, as shown exemplarily in Fig. $2 b$. Therefore, it was not feasible to evaluate the effect of the sample size on the obtained mass loss based on either the applied treatment temperature or the treatment time. This also applied to the variation of the $\mathrm{L} / \mathrm{S}$ ratio, which resulted in large differences in vessel load. Therefore, the mass loss data were further analyzed as a function of the severity factor, log $\mathrm{R}_{0 \mathrm{HWE}}$. The severity factor considered the additional heat exposure during the heating phase prior to the treatment phase and combined the effect of treatment temperature and time into a single value. The HWE treatments caused a nearly linear loss in mass as a function of the severity factor of both small and large samples (Fig. 3a). However, small samples resulted in a faster increase in mass loss than large samples. While small samples reached a maximum mass loss of ca.
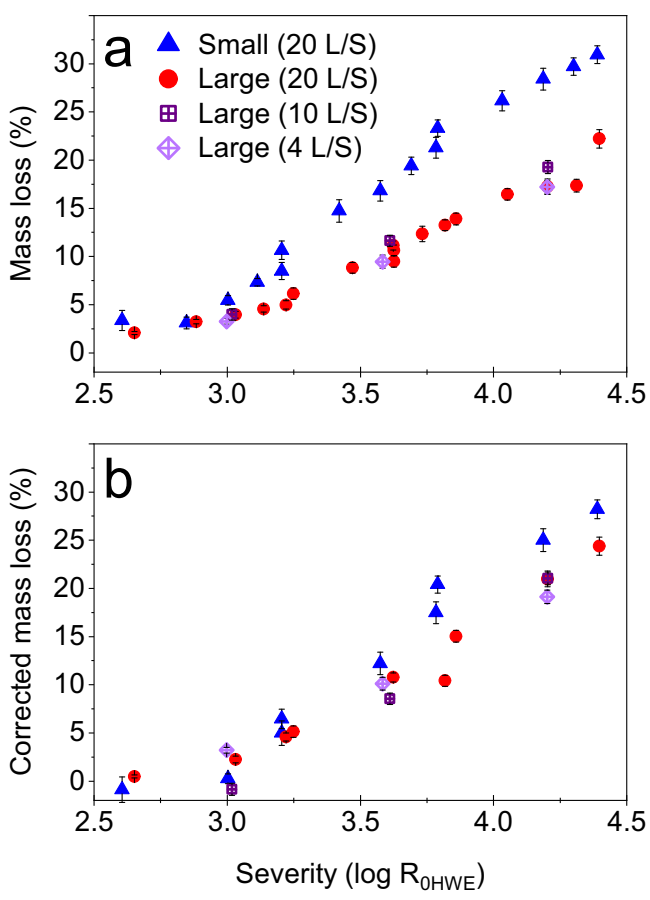

Fig. 3 Mass loss (in \%, a) and corrected mass loss (in \%, b) of Scots pine sapwood in relation to the hot water extraction severity $\left(\log \mathrm{R}_{0 \mathrm{HWE}}\right)$; error bars represent the standard deviation for mass loss and corrected mass loss

$31 \%$, the mass loss recorded for large samples did not exceed $23 \%$. This result is consistent with previous research on the effect of wood size based on wood chips or other small wood particles [30-32].

The difference between small and large samples became less prominent when considering the corrected mass loss that was based on the dry and extractive-free mass before and after the process (Fig. 3b). This showed that differences in the amount of acetone-soluble compounds were a major factor for the mass loss differences between the two sample sizes. For small samples, the corrected extractive-free mass loss was lower than the uncorrected mass loss, due to the decrease in the reference dry mass caused by acetone extraction. In contrast, the corrected mass loss exceeded the mass loss for large samples that were treated at high treatment severity. This indicated that significant amounts of acetone-soluble decomposition products remained in the large samples after treatment and water-leaching and did not contribute to the mass loss. This was in line with the explanations of Krogell et al. [30], Li et al. [31], and Song et al. [32] who suggested that hemicellulose dissolution is hindered in larger wood particles because of longer fiber to fiber diffusion and wood matrix mass transfer distances. Due to the builtup of wood, fiber to fiber diffusion rates differ between the anatomical dimensions. In particular, a faster transport of soluble compounds can be expected in the longitudinal direction compared with the transversal directions. 
Therefore, the rate of diffusion of soluble compounds from the wood into the treatment liquid may not necessarily be proportional to the volume of woodblocks. However, since the dimensional relations of small and large samples were the same $\left(1 \mathrm{n} \times 1 \mathrm{n} \times 2 \mathrm{~nm}^{3}, \mathrm{R} \times \mathrm{T}\right.$ $\times$ L), differences in diffusion between the anatomical directions were not further investigated in this study. Nonetheless, small samples led to a higher corrected mass loss than large samples when exceeding a severity factor of ca. 3.3. The mass loss results may have been influenced by a potential temperature gradient within the samples, particularly during the heating phase of the HWE treatment. Thereby, it is possible that it took longer until the core of the large samples reached the target temperature, which would have resulted in areas with less intense wood decomposition. However, but since the samples were fully water-saturated before the HWE treatment, fast heat transfer within the samples was expected. Therefore, an alternative explanation for the small dependence of the corrected mass loss on the sample size could be the presence of further decomposition products that were not soluble in acetone.

For selected treatment temperatures and time, the effect of the L/S ratio was analyzed additionally. One may have speculated that the diffusion of decomposition products was also influenced by the concentration gradient between the sample and the surrounding treatment water. Despite large variations in L/S ratio, however, its effect on mass loss was negligible (Fig. 3 a and b). Presumably, the water-leaching of the samples following the HWE treatment removed hydrolysates from the wood and diminished dissolution differences between different $\mathrm{L} / \mathrm{S}$ ratios [29].

\subsection{SEM analysis of the solid wood residue}

The SEM images taken from radial surfaces (Fig. 4) had major visible morphological differences between samples. In contrast to reference samples, depositions on the cell walls were observed after HWE and water-leaching. This was especially visible for small samples, where a rough deposition layer partly covered the cell wall surfaces (Fig. 4a). For the same samples, fewer depositions were observed after extraction with acetone, as evident from the smoother cell wall surface, which indicated the dissolution and removal of these depositions from the surfaces of small samples (Fig. 4b). Compared with small samples, less depositions were observed on cell walls of large samples. Only the most intensively treated large samples had some depositions on the cell walls (Fig. 4c). However, HWE-treated, large samples that were both water-leached and acetone-extracted had numerous spherical droplets on their cell walls (Fig. 4d). The diameters of these droplets were in the range between 0.5 and $2.0 \mu \mathrm{m}$. The number of droplets was especially high on large samples treated at the highest severity (Fig. 4d).

The formation of droplets on the surface of HWE-treated wood material has been recorded previously by PelaezSamaniego et al. [8] and Troncoso et al. [46]. Droplets and other depositions have been assigned to either solubilized, coalesced and migrated lignin $[47,48]$, repolymerized carbohydrate degradation products [49], or a combination of the two [50]. However, differences in the formation and shape of depositions on HWE-treated wood between different sample sizes have not been reported previously. Presumably, decomposition products remained in large samples that did not become soluble during extraction with acetone but migrated to the cell wall surfaces to form droplets. However, SEM did not
Fig. 4 SEM images taken from middle of the radial surface of a water-leached (W) and $\mathbf{b}$ waterleached and acetone-extracted (W + Ac) small Scots pine sapwood sample $13\left(170^{\circ} \mathrm{C}, 120 \mathrm{~min}\right)$, and c water-leached and $\mathbf{d}$ waterleached and acetone-extracted large Scots pine sapwood sample $15\left(170{ }^{\circ} \mathrm{C}, 200 \mathrm{~min}\right)$; red line shows $10-\mu \mathrm{m}$ scale bar
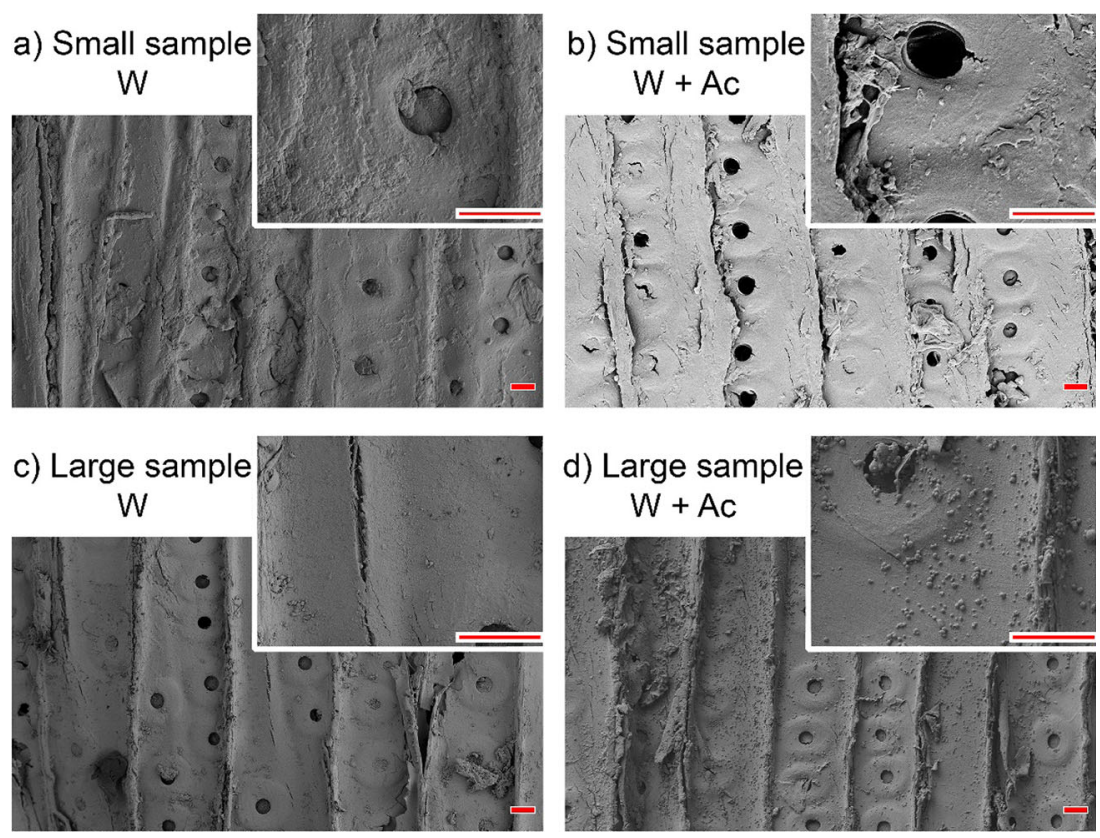
Fig. 5 Changes in amount (\% of reference) of cellulose (a),

hemicelluloses (b), lignin (c), and acetone-soluble extractives (d) in the solid residue in relation to on the mass loss (in \%) of Scots pine sapwood; the dashed line highlights the reference value $(=$ $100 \%$ )
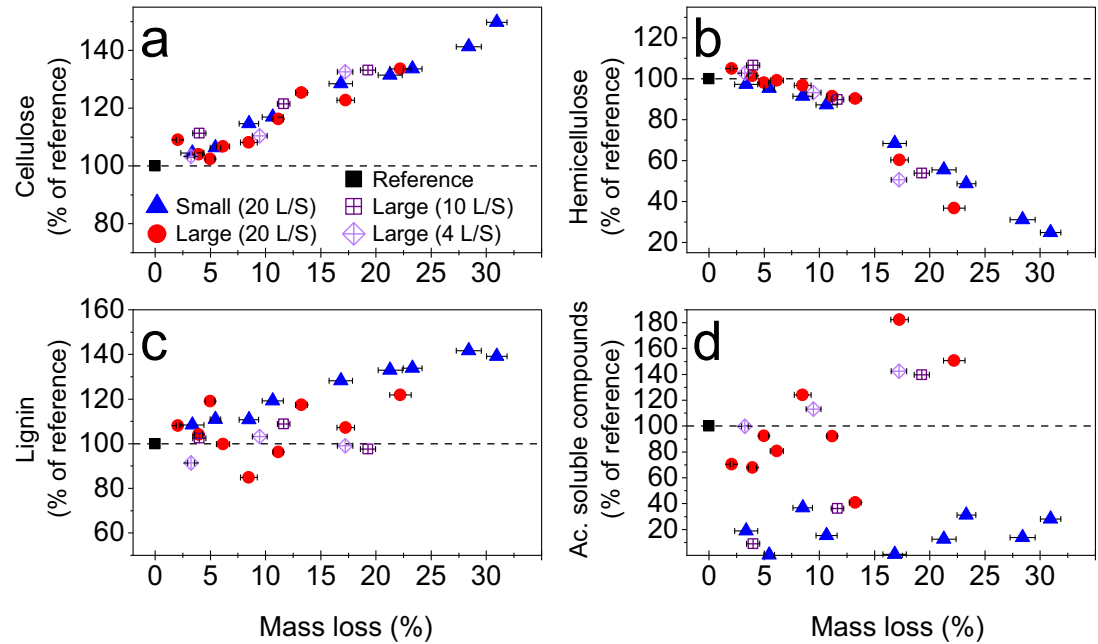

provide information on their chemical structure; hence, further research is required to explain the differences between residual decomposition products in small and large samples.

\subsection{Chemical composition of the solid residue}

Chemical composition changes in the solid wood residue were not shown as a function of the severity index, since the more efficient removal of wood constituents for small samples was already shown by the mass loss data. Instead, composition changes were shown as a function of mass loss (Fig. 5) and it was analyzed if differences in the chemical composition occurred when both samples dimensions reached the same mass loss.

In line with previous studies on hydrothermal wood decomposition [16], hemicelluloses were preferentially degraded, resulting in a decrease in hemicellulose content and an increase in cellulose content with increasing mass loss (Fig. $5 \mathrm{a}$ and $\mathrm{b}$ ). The cellulose and hemicellulose contents changed as nearly linear functions of the mass loss, irrespective of the sample size or the L/S ratio. However, in contrast to the changes in the residual carbohydrate contents, the changes in the amounts of lignin and acetone-soluble compounds as a function of the mass loss were dependent on the sample size (Fig. 5c and d). For small samples, the lignin content increased linearly with increasing mass loss, due to the preferential removal of hemicelluloses. Furthermore, the amount of acetonesoluble extractives decreased rapidly to about $20 \%$ of the reference amount, which indicated the facile dissolution of degradation products and native wood extractives into the bulk water. The treatment of large samples, however, resulted in a high data scattering of both the content of lignin and acetonesoluble compounds. Some treatments even resulted in an increase in acetone-soluble compounds, which showed that a proportion of depolymerized cell wall constituents remained within the large samples and did not dissolve during the HWE treatment or during the preceding water-leaching.

\subsection{Carbohydrates and other compounds in the extraction liquids}

Figure 6 shows the amount of soluble compounds in the extraction liquids in relation to the treatment severity. There was a deviation between the wood mass loss determined for the solid residue and the total amount of compounds that were detected in the extraction liquid, and this difference was denoted as an undetermined mass loss. Presumably, weak acids and furan derivatives were produced when poly- and monocarbohydrates from

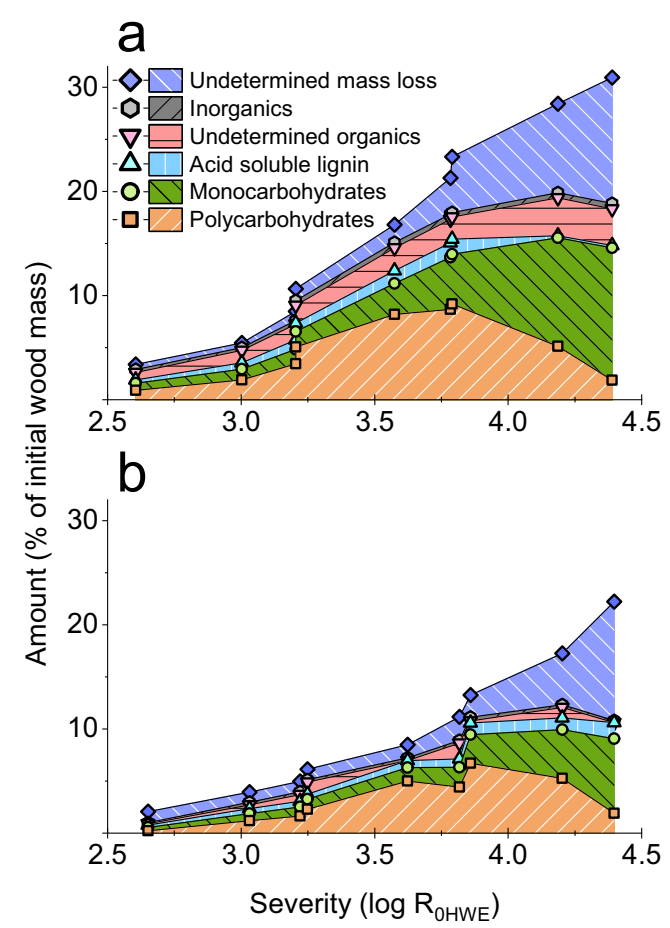

Fig. 6 Amount (in \%) of soluble compounds extracted from a small and b large Scots pine sapwood samples in relation to the treatment severity ( $\log \mathrm{R}_{0 \mathrm{HWE}}$ ); the undetermined mass loss, which was calculated by subtracting the total dissolved solids in extraction liquid from the wood mass loss, is also shown 


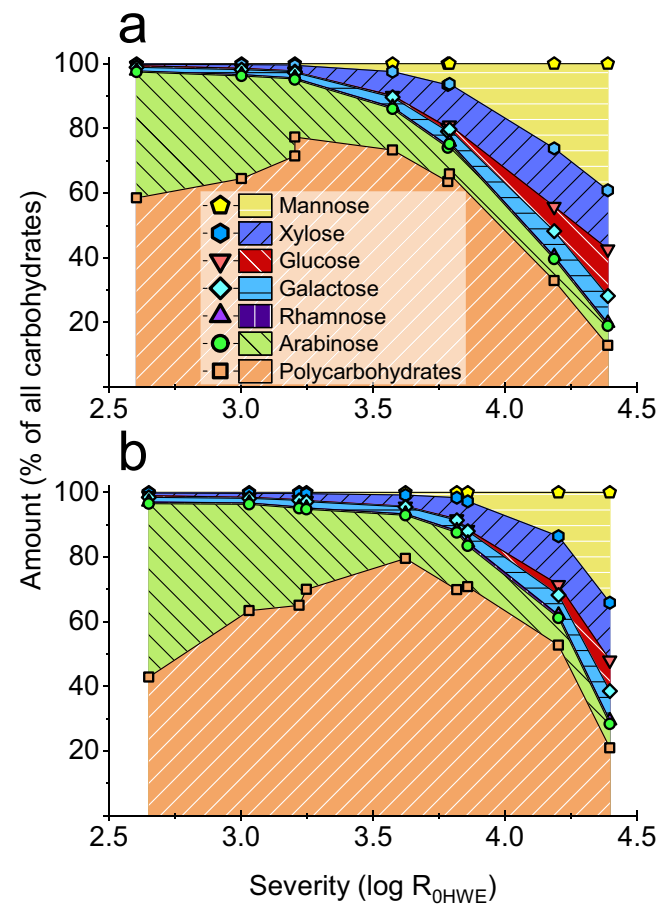

Fig. 7 Amount (in \% of all carbohydrates) of polycarbohydrates, arabinose, rhamnose, galactose, glucose, xylose, and mannose extracted from a small and $\mathbf{b}$ large Scots pine sapwood samples in relation to the treatment severity (log $\mathrm{R}_{0 \mathrm{HWE}}$ )

softwood degraded $[19,51]$. Weak acids and furan derivatives may have been emitted as volatile compounds during the determination of total dissolved solids. The amount of undetermined mass loss increased with the treatment severity and was evident for small and large samples. Nonetheless, the amount of compounds that were determined in the extraction liquids increased continuously until reaching a severity of ca. $4.2-4.3$ and decreased slightly when the severity index increased further. The majority of the detected compounds in the extraction liquids were poly- and monocarbohydrates. Most of the carbohydrates that dissolve into extraction liquid during HWE treatments are degradation products of hemicellulose [20]. Regardless of the sample size, the largest quantity of polycarbohydrates was found at a treatment severity of ca. 3.8-3.9, and the total amount of carbohydrates was largest at a treatment severity of ca. 4.2-4.3. In line with the effect of the sample size on the wood mass loss, larger quantities of soluble compounds, i.e., carbohydrates, were found in the extraction liquid of small samples. However, the amount of obtained carbohydrates in the extraction liquids was low when compared with that in previous studies that treated small wood chips or sawdust [30-32]. As an example, Krogell et al. [30] obtained $95 \%$ of total hemicellulose content when treating spruce wood with particle size $0.5-0.7 \mathrm{~mm}$ at $170{ }^{\circ} \mathrm{C}$ for $2 \mathrm{~h}$, whereas less than $65 \%$ of total hemicellulose content was obtained in the present study. This underlines the effect of the wood size on the carbohydrate yield during HWE.

In contrast to the quantity of soluble compounds in the extraction liquid of small and large samples, the changes in the composition of the extraction liquid in relation to the treatment severity were similar for both sample sizes. Figure 7 shows the changes in the carbohydrate composition at different treatment severities. At low treatment severities, easily extractable arabinose [52] and polycarbohydrates were most prominent. The proportion of polycarbohydrates increased further until more than $70 \%$ of all carbohydrates in the extraction liquid were represented by polycarbohydrates. The highest ratio of polycarbohydrates to the total amount of carbohydrates was reached at a treatment severity of ca. 3.2 and 3.7 for small and large samples, respectively. At higher treatment severities, the proportion of polycarbohydrates decreased and monocarbohydrates became more dominant. This illustrated the more intense hydrolytic cleavage of the glycosidic bonds in carbohydrates when the treatment temperature was increased and/or when the treatment duration was prolonged. At the highest treatment severity, mannose was the most abundant carbohydrate in the extraction liquid, followed by xylose, glucose, and galactose, which corresponded roughly to the composition of the main hemicelluloses in softwoods, galactoglucomannan and arabinoglucuronoxylan [52].
Table 2 Results of the chemical analysis of the extraction liquids after HWE treatments of large Scots pine sapwood samples at different $\mathrm{L} / \mathrm{S}$ ratios, with a peak duration of $120 \mathrm{~min}$

\begin{tabular}{llrllll}
\hline $\begin{array}{l}\text { Temperature } \\
\left({ }^{\circ} \mathrm{C}\right)\end{array}$ & L/S ratio & Severity & $\mathrm{pH}$ & $\begin{array}{l}\text { TDS } \\
(\% \text { of initial } \\
\text { dry mass })\end{array}$ & $\begin{array}{l}\text { Carbohydrates } \\
\text { (\% of initial } \\
\text { dry mass })\end{array}$ & $\begin{array}{l}\text { Polycarbohydrates } \\
\text { (\% of all } \\
\text { carbohydrates })\end{array}$ \\
\hline 130 & 4 & 3.00 & 3.26 & 2.12 & 1.53 & 65.42 \\
& 10 & 3.02 & 3.37 & 2.10 & 1.53 & 67.65 \\
& 20 & 3.03 & 3.24 & 2.96 & 1.88 & 63.43 \\
150 & 4 & 3.58 & 3.06 & 6.58 & 5.53 & 77.07 \\
& 10 & 3.61 & 3.23 & 9.09 & 8.11 & 75.37 \\
170 & 20 & 3.62 & 3.12 & 8.91 & 6.32 & 69.91 \\
& 4 & 4.20 & 2.88 & 9.36 & 7.25 & 46.45 \\
& 10 & 4.20 & 3.19 & 12.85 & 10.94 & 51.00 \\
& 20 & 4.20 & 3.04 & 12.33 & 9.94 & 52.74 \\
\hline
\end{tabular}


The effect of the $\mathrm{L} / \mathrm{S}$ ratio on the compounds in the extraction liquid was small (Table 2). This is in line with Leschinsky et al. [29], who suggested that extensive washing removes soluble hydrolysates that reside in wood pores, which would diminish dissolution differences between different $\mathrm{L} / \mathrm{S}$ ratios. However, for treatment temperatures of 150 and $170{ }^{\circ} \mathrm{C}$, the amount of TDS and carbohydrates was lower when the L/S ratio was 4 . This may be due to the more rapid degradation of carbohydrates caused by higher acidity [27]. Furthermore, a low L/S ratio may reduce the concentration gradient between wood and extraction liquid that promotes the diffusion of soluble compounds.

\section{Conclusions}

For a broad range of HWE conditions, our results demonstrated the effect of the wood size on the decomposition rate and the carbohydrate yield. By increasing the wood size, a lower mass loss of the solid residue and a lower carbohydrate yield in the extraction liquid was recorded at the same treatment severity. This was assigned to longer distances for diffusion and mass transfer of decomposition products from large wood blocks into the extraction liquid. The difference in mass loss between small and large samples was mostly due to a higher amount of acetonesoluble compounds in large samples. However, although the quantity of the obtained decomposition products differed, the composition of the extraction liquids and its dependence on the treatment severity was nearly unaffected by the sample size. The results may help in optimizing the treatment conditions for maximizing the carbohydrate yield at low energy consumption, especially in view of a potential application to larger wood pieces for the use in engineered wood products.

Acknowledgments This work made use of the Aalto University Nanomicroscopy Center (Aalto-NMC) premises.

\section{CRediT author statement}

- Suvi Kyyrö: conceptualization, methodology, validation, formal analysis, investigation, writing- original draft, and visualization.

- Michael Altgen: conceptualization, validation, writing- review and editing, and supervision.

- Lauri Rautkari: conceptualization, writing- review and editing, supervision, and funding acquisition.

Funding information Open access funding provided by Aalto University. This study is financially supported by the Academy of Finland (grant no. 309881) and the South Savo Regional Council of the European Regional Development Fund (project code A7389).

\section{Compliance with ethical standards}

Conflict of interest The authors declare that they have no competing interests.
Open Access This article is licensed under a Creative Commons Attribution 4.0 International License, which permits use, sharing, adaptation, distribution and reproduction in any medium or format, as long as you give appropriate credit to the original author(s) and the source, provide a link to the Creative Commons licence, and indicate if changes were made. The images or other third party material in this article are included in the article's Creative Commons licence, unless indicated otherwise in a credit line to the material. If material is not included in the article's Creative Commons licence and your intended use is not permitted by statutory regulation or exceeds the permitted use, you will need to obtain permission directly from the copyright holder. To view a copy of this licence, visit http://creativecommons.org/licenses/by/4.0/.

\section{References}

1. Kapu NS, Trajano HL (2014) Review of hemicellulose hydrolysis in softwoods and bamboo. Biofuel Bioprod Bior 8:857-870. https://doi.org/10.1002/bbb.1517

2. Wikberg H, Grönberg V, Jermakka J, Kemppainen K, Kleen M, Laine C, Paasikallio V, Oasmaa A (2015) Hydrothermal refining of biomass - an overview and future perspectives. Tappi J 14:195207. https://doi.org/10.32964/tj14.3.195

3. Guan W, Xu G, Duan J, Shi S (2018) Acetone-butanol-ethanol production from fermentation of hot-water-extracted hemicellulose hydrolysate of pulping woods. Ind Eng Chem Res 57:775-783. https://doi.org/10.1021/acs.iecr.7b03953

4. Ebringerová A, Heinze T (2000) Xylan and xylan derivatives biopolymers with valuable properties, 1 . Naturally occurring xylans structures, isolation procedures and properties. Macromol Rapid Commun 21:542-556. https://doi.org/10.1002/15213927(20000601)21:9<542::AID-MARC542>3.0.CO;2-7

5. Rissanen JV, Grénman H, Xu C, Willför S, Murzin DY, Salmi T (2014) Obtaining spruce hemicelluloses of desired molar mass by using pressurized hot water extraction. ChemSusChem 7:29472953. https://doi.org/10.1002/cssc.201402282

6. Yoon S-H, Van Heiningen A (2008) Kraft pulping and papermaking properties of hot-water pre-extracted loblolly pine in an integrated forest products biorefinery. Tappi J 7:22-27

7. Andrusyk L, Oporto GS, Gardner DJ, Neivandt DJ (2008) Wood plastic composites manufactured from hot water extracted wood. Part I: Mechanical evaluation. In: Proceedings of the 51st International Convention of Society of Wood Science and Technology. Concepción, Chile

8. Pelaez-Samaniego MR, Yadama V, Garcia-Perez T, Lowell E, Amidon T (2014) Effect of hot water extracted hardwood and softwood chips on particleboard properties. Holzforschung 68:807815. https://doi.org/10.1515/hf-2013-0150

9. Sattler C, Labbé N, Harper D, Elder T, Rials T (2008) Effects of hot water extraction on physical and chemical characteristics of oriented strand board (OSB) wood flakes. CLEAN - Soil Air Water 36: 674-681. https://doi.org/10.1002/clen.200800051

10. Rowell RM, Ibach RE, McSweeny J, Nilsson T (2009) Understanding decay resistance, dimensional stability and strength changes in heat-treated and acetylated wood. Wood Mater Sci Eng 4:14-22. https://doi.org/10.1080/17480270903261339

11. Altgen M, Uimonen T, Rautkari L (2018) The effect of de- and repolymerization during heat-treatment on the mechanical behavior of Scots pine sapwood under quasi-static load. Polym Degrad Stab 147:197-205. https://doi.org/10.1016/j.polymdegradstab.2017.12. 007

12. Lillqvist K, Källbom S, Altgen M, Belt T, Rautkari L (2019) Water vapour sorption properties of thermally modified and pressurised 
hot-water-extracted wood powder. Holzforschung 73:1059-1068. https://doi.org/10.1515/hf-2018-0301

13. Altgen M, Kyyrö S, Paajanen O, Rautkari L (2020) Resistance of thermally modified and pressurized hot water extracted Scots pine sapwood against decay by the brown-rot fungus Rhodonia placenta. Eur J Wood Wood Prod 78:161-171. https://doi.org/10.1007/ s00107-019-01482-Z

14. Altgen M, Willems W, Hosseinpourpia R, Rautkari L (2018) Hydroxyl accessibility and dimensional changes of Scots pine sapwood affected by alterations in the cell wall ultrastructure during heat-treatment. Polym Degrad Stab 152:244-252. https://doi.org/ 10.1016/j.polymdegradstab.2018.05.005

15. Conner AH (1984) Kinetic modeling of hardwood prehydrolysis. Part I. Xylan removal by water prehydrolysis. Wood Fiber Sci 16: 268-277

16. Garrote G, Domínguez H, Parajó JC (1999) Hydrothermal processing of lignocellulosic materials. Holz Roh Werkst 57:191-202. https://doi.org/10.1007/s001070050039

17. Jeong S-Y, Lee J-W (2015) Chapter 5 - Hydrothermal treatment. In: Pandey A, Negi S, Binod P, Larroche C (eds) Pretreatment of Biomass. Elsevier, Amsterdam, pp 61-74. https://doi.org/10.1016/ B978-0-12-800080-9.00005-0

18. Leppänen K, Spetz P, Pranovich A, Hartonen K, Kitunen V, Ilvesniemi H (2011) Pressurized hot water extraction of Norway spruce hemicelluloses using a flow-through system. Wood Sci Technol 45:223-236. https://doi.org/10.1007/s00226-010-0320-z

19. Nitsos CK, Choli-Papadopoulou T, Matis KA, Triantafyllidis KS (2016) Optimization of hydrothermal pretreatment of hardwood and softwood lignocellulosic residues for selective hemicellulose recovery and improved cellulose enzymatic hydrolysis. ACS Sustain Chem Eng 4:4529-4544. https://doi.org/10.1021/ acssuschemeng.6b00535

20. Nitsos CK, Matis KA, Triantafyllidis KS (2013) Optimization of hydrothermal pretreatment of lignocellulosic biomass in the bioethanol production process. ChemSuschem 6:110-122. https:// doi.org/10.1002/cssc.201200546

21. Borrega M, Nieminen K, Sixta H (2011) Effects of hot water extraction in a batch reactor on delignification of birch wood. BioResources 6:1890-1903. https://doi.org/10.15376/biores.6.2. 1890-1903

22. Nuopponen M, Vuorinen T, Jämsä S, Viitaniemi P (2005) Thermal modifications in softwood studied by FT-IR and UV resonance raman spectroscopies. J Wood Chem Technol 24:13-26. https:// doi.org/10.1081/WCT-120035941

23. Song T, Pranovich A, Sumerskiy I, Holmbom B (2008) Extraction of galactoglucomannan from spruce wood with pressurized hot water. Holzforschung 62:659-666. https://doi.org/10.1515/HF. 2008.131

24. Örså F, Holmbom B, Thornton J (1997) Dissolution and dispersion of spruce wood components into hot water. Wood Sci Technol 31: 279-290. https://doi.org/10.1007/BF00702615

25. Kleen M, Pranovich A, Willför S (2016) Statistical modeling of pressurized hot-water batch extraction (PHWE) to produce hemicelluloses with desired properties. Holzforschung 70:633-640. https://doi.org/10.1515/hf-2015-0048

26. Pedersen M, Meyer AS (2010) Lignocellulose pretreatment severity - relating $\mathrm{pH}$ to biomatrix opening. New Biotechnol 27:739-750. https://doi.org/10.1016/j.nbt.2010.05.003

27. Tunc MS (2014) Effect of Liquid to Solid Ratio on Autohydrolysis of Eucalyptus globulus Wood Meal. BioResources 9:3014-3024. https://doi.org/10.15376/biores.9.2.3014-3024

28. Garrote G, Domínguez H, Parajó JC (1999) Mild autohydrolysis: an environmentally friendly technology for xylooligosaccharide production from wood. J Chem Technol Biotechnol 74:1101-1109. https://doi.org/10.1002/(SICI)1097-4660(199911)74:11<1101:: AID-JCTB146>3.0.CO;2-M
29. Leschinsky M, Sixta H, Patt R (2009) Detailed mass balances of the autohydrolysis of eucalyptus globulus at $170{ }^{\circ} \mathrm{C}$. BioResources 4 : 687-703

30. Krogell J, Korotkova E, Eränen K, Pranovich A, Salmi T, Murzin D, Willför S (2013) Intensification of hemicellulose hot-water extraction from spruce wood in a batch extractor - effects of wood particle size. Bioresource Technol 143:212-220. https://doi.org/10. 1016/j.biortech.2013.05.110

31. Li Z, Qin M, Xu C, Chen X (2013) Hot Water Extraction of hemicelluloses from Aspen wood chips of different sizes. BioResources 8:5690-5700. https://doi.org/10.15376/biores.8.4.5690-5700

32. Song T, Pranovich A, Holmbom B (2012) Hot-water extraction of ground spruce wood of different particle size. BioResources 7 : 4214-4225

33. Overend R, Chornet E (1987) Fractionation of lignocellulosics by steam-aqueous pretreatments. Philos Trans R Soc Math Phys Eng Sci 321:523-536. https://doi.org/10.1098/rsta.1987.0029

34. Carvalheiro F, Silva-Fernandes T, Duarte LC, Gírio FM (2009) Wheat straw autohydrolysis: process optimization and products characterization. Appl Biochem Biotech 153:84-93. https://doi. org/10.1007/s12010-008-8448-0

35. Chen S-F, Mowery RA, Chambliss CK, van Walsum GP (2007) Pseudo reaction kinetics of organic degradation products in diluteacid-catalyzed corn stover pretreatment hydrolysates. Biotechnol Bioeng 98:1135-1145. https://doi.org/10.1002/bit.21480

36. Altgen M, Willems W, Militz H (2016) Wood degradation affected by process conditions during thermal modification of European beech in a high-pressure reactor system. Eur J Wood Wood Prod 74:653-662. https://doi.org/10.1007/s00107-016-1045-y

37. TAPPI (1997) Solvent extractives of wood and pulp (Proposed revision of T $204 \mathrm{~cm}-97)$. TAPPI Standards

38. SFS (2002) Moisture content of a piece of sawn timber. Part 1: Determination by oven dry method. Suomen standardisoimisliitto. Finnish Standards Association SFS.

39. TAPPI (2002) Ash in wood, pulp, paper and paperboard: combustion at $525{ }^{\circ} \mathrm{C}(\mathrm{T} 211 \mathrm{om}-02)$. TAPPI Standards

40. Sluiter A, Hames B, Ruiz R, Scarlata C, Sluiter J, Templeton D, Crocker D (2012) Determination of structural carbohydrates and lignin in biomass: laboratory analytical procedure (LAP). Technical Report NREL/TP-510-42618. National Renewable Energy Laboratory (NREL), USA.

41. Amidon TE, Liu S (2009) Water-based woody biorefinery. Biotechnol Adv 27:542-550. https://doi.org/10.1016/j.biotechadv. 2009.04.012

42. Janson J (1970) Calculation of the polysaccharide composition of wood and pulp. Pap Puu - Pap Tim 52:323-329

43. SFS (2008) Jätteiden karakterisointi. Liuenneiden aineiden kokonaismäärän määrittäminen vedestä ja eluaateista. Characterization of waste. Determination of total dissolved solids (TDS) in water and eluates. Suomen standardisoimisliitto. Finnish Standards Association SFS.

44. SFS (1990) Veden, lietteen ja sedimentin kuiva-aineen ja hehkutusjäännöksen määritys. Determination of total residue and total fixed residue in water, sludge and sediment. Suomen standardisoimisliitto. Finnish Standards Association SFS.

45. Sluiter A, Hames B, Ruiz R, Scarlata C, Sluiter J, Templeton D (2008) Determination of sugars, byproducts, and degradation products in liquid fraction process samples: laboratory analytical procedure (LAP). Technical Report NREL/TP-510-42623. National Renewable Energy Laboratory (NREL), USA.

46. Troncoso E, Castillo R, Valenzuela R, Reyes P, Freer J, Norambuena M, Rodríguez J, Parra C (2017) Chemical and microstructural changes in eucalyptus globulus fibers subjected to four different pretreatments and their influence on the enzymatic hydrolysis. J Chil Chem Soc 62:3442-3446. https://doi.org/10.4067/ S0717-97072017000200005 
47. Donohoe BS, Decker SR, Tucker MP, Himmel ME, Vinzant TB (2008) Visualizing lignin coalescence and migration through maize cell walls following thermochemical pretreatment. Biotechnol Bioeng 101:913-925. https://doi.org/10.1002/bit.21959

48. Selig MJ, Viamajala S, Decker SR, Tucker MP, Himmel ME, Vinzant TB (2007) Deposition of lignin droplets produced during dilute acid pretreatment of maize stems retards enzymatic hydrolysis of cellulose. Biotechnol Progr 23:1333-1339. https://doi.org/10. 1021/bp0702018

49. Shinde SD, Meng X, Kumar R, Ragauskas AJ (2018) Recent advances in understanding the pseudo-lignin formation in a lignocellulosic biorefinery. Green Chem 20:2192-2205. https://doi.org/10. 1039/C8GC00353J
50. Zhuang J, Wang X, Xu J, Wang Z, Qin M (2017) Formation and deposition of pseudo-lignin on liquid-hot-water-treated wood during cooling process. Wood Sci Technol 51:165-174. https://doi. org/10.1007/s00226-016-0872-7

51. Palmqvist E, Hahn-Hägerdal B (2000) Fermentation of lignocellulosic hydrolysates. II: inhibitors and mechanisms of inhibition. Biosource Technol 74:25-33. https://doi.org/10.1016/S09608524(99)00161-3

52. Sjöström E (1993) Wood Chemistry, fundamentals and applications. https://doi.org/10.1016/C2009-0-03289-9

Publisher's Note Springer Nature remains neutral with regard to jurisdictional claims in published maps and institutional affiliations. 